\title{
Thermal Impact from a Thermoelectric Power Plant on a Tropical Coastal Lagoon
}

Authors: Cardoso-Mohedano J. G ${ }^{\text {a }}$; Bernardello R. ; Sanchez-Cabeza J. A.*a; Ruiz-Fernández A. C. ${ }^{\text {c; }}$; Alonso-Rodriguez R. ${ }^{\mathrm{c}}$; Cruzado A. ${ }^{\mathrm{d}}$.

a Departamento de Procesos Costeros y Oceánicos, Instituto de Ciencias del Mar y Limnología, Universidad Nacional Autónoma de México, 04510, México D.F., México.

${ }^{\mathrm{b}}$ National Oceanography Centre, Southampton SO14 3ZH, UK.

c Unidad Académica Mazatlán, Instituto de Ciencias del Mar y Limnología, Universidad Nacional Autónoma de México, Mazatlán 82000, Sinaloa, México

${ }^{\mathrm{d}}$ Oceans Catalonia International SL, Anselm Clavé, 8, 17300 Blanes, Spain

*Corresponding author. Tel: +52 (55) 56225693

Email address: jasanchez@cmarl.unam.mx

\begin{abstract}
Tropical coastal areas are sensitive ecosystems to Climate Change, mainly due to sea level rise and increasing water temperatures. Furthermore, they may be subject to numerous stresses, including heat releases from energy production. The Urias coastal lagoon (SE Gulf of California), a sub-tropical tidal estuary, receives cooling water releases from a thermoelectric power plant, urban and industrial wastes, and shrimp farm discharges. In order to evaluate the plant thermal impact, we measured synchronous temperature time series close and far from the plant. Furthermore, in order to discriminate the thermal pollution impact from natural variability, we used a high-resolution hydrodynamic model forced by, amongst others, cooling water release, by simulating a continuous flow $\left(7.78 \mathrm{~m}^{3} \mathrm{~s}^{-1}\right)$ at $6{ }^{\circ} \mathrm{C}$ overheating temperature. The model results and the field data indicated that the main thermal impact was temporally restricted to the warmest months, spatially restricted to the surface layers (above $0.6 \mathrm{~m}$ ) and distributed along the shoreline within $100 \mathrm{~m}$ of the release point. The methodology and results of this study can be extrapolated to tropical coastal lagoons that receive heat discharges.
\end{abstract}

Keywords: Temperature. Thermal pollution. Thermoelectric-power-plant. Coastal lagoon. Princeton Ocean Model. 


\section{Introduction}

The United Nations Joint Group of Experts on the Scientific Aspects of Marine Environment Protection defines pollution of the marine environment as "the introduction by man, directly or indirectly, of substances or energy into the marine environment (including estuaries) which results in such deleterious effects as harm to living resources, hazards to human health, hindrance to marine activities including fishing, impairment of quality for use of sea water and reduction of amenities", including the impacts of thermal discharges in the marine environment (GESAMP 1984). One of the most common sources of heat pollution to aquatic ecosystems is power generation.

In order to produce electricity, coastal thermal and nuclear power plants use sea water for cooling, which is heated and released back to the ecosystems causing environmental impacts (Crema and Pagliai 1980; Jiang et al. 2008; Teixeira et al. 2012; Teixeira et al. 2009; Verones et al. 2010). Globally, in 2002 the fossil fuel and nuclear consumption was 9,000 million metric ton oil equivalent per year (BP-AMOCO 2002; IEA 1998) producing 1,014 kWh of heat. This energy overheats the Earth surface by $0.02 \mathrm{~W} \mathrm{~m}^{2}$ (Nordell 2003). In Mexico, $84 \%$ of the electricity is produced by thermal and nuclear power plants, which consume $~ 5 \%$ of the licensed water (CONAGUA 2011).

Thermal pollution can be especially serious in tropical zones, where sea water temperature may be near the upper tolerance limits of some marine organism (Langford 2009; Poornima et al. 2005). Moreover, in the present scenario of Climate Change, the environmental thermal impact can become even more critical (Kimmerer and Weaver 2013). It is therefore relevant to develop tools that facilitate the assessment of environmental impacts and risks in coastal ecosystems due to thermal pollution.

The Urias Coastal Lagoon (UCL) is a sub-tropical coastal lagoon in northwestern Mexico (SE Gulf of California), under significant environmental pressure due to the proximity of Mazatlan City, which has 438,434 inhabitants (2010) that can increase by 50\% during the tourist season (INEGI 2013). The Mazatlan port is on the lagoon and provides valuable services such as commerce, tourism, fishing, seafood processing and naval industry (Villalba 1989). The estuary also receives cooling waters from the thermoelectric power plant "José Aceves Pozos" at a flow rate of $7.8 \mathrm{~m}^{3} \mathrm{~s}^{-1}$, and 2-6 ${ }^{\circ} \mathrm{C}$ of overheating temperature (Alvarez León 1980). In the present work, we measured temperature timeseries and implemented a high-resolution model (50 m x $50 \mathrm{~m}$ ) in order to assess the thermal impact of the cooling waters releases from this thermal plant in the lagoon. The methodology and results of this work may be useful to the study of thermal impacts in tropical coastal lagoons worldwide.

\section{Materials and Methods}

\subsection{Study Area}

Figure 1. Bathymetry of the Urias Coastal lagoon (depth contours in meters) and Thermoelectric Impact Station (red star) and Reference Station (blue star).

The Urias coastal lagoon $\left(23^{\circ} 11^{\prime} \mathrm{N}-106^{\circ} 22^{\prime} \mathrm{W}\right)$ is adjacent to Mazatlán City, Sinaloa State, on the Pacific coast of Mexico (SE Gulf of Mexico). It has a surface area of $18 \mathrm{~km}^{2}$ and a length of $17 \mathrm{~km}$. This estuary has been described as a coastal lagoon with an internal platform barrier (Lankford 1977). 
The lagoon circulation is tidally dominated and characterized by a mixed tide with an average range of about $1 \mathrm{~m}$. Montaño-Ley and co-workers (2008) report a maximum tidal velocity of $0.6 \mathrm{~m} \mathrm{~s}^{-1}$ in the navigation channel and predict tidal ranges of $1.2 \mathrm{~m}$ under the spring tide. Cardoso-Mohedano and coworkers (2014) describe that the lagoon has an anti-estuarine behavior and its complex lagoon morphology causes strong differences in the speed of the tidal currents among the three main lagoon areas, with vertically average speeds of $0.91 \mathrm{~m} \mathrm{~s}^{-1}$ in the Harbor Area, $0.83 \mathrm{~m} \mathrm{~s}^{-1}$ in the Intermediate Area and $0.31 \mathrm{~m} \mathrm{~s}^{-1}$ in the Upper Area. The mean water age in each area is $\sim 15$ days, $\sim 30$ days and $\sim 70$ days, respectively.

According to Álvarez-León (1977), the average annual rainfall in the area is $0.8 \mathrm{~m}$, the average annual surface temperature is $25^{\circ} \mathrm{C}$ and the monthly average temperature ranges from $19.7^{\circ} \mathrm{C}$ in February to $28{ }^{\circ} \mathrm{C}$ in August. The average annual salinity has been reported to have a value of 34 PSU (practical salinity unit), a maximum during the drought season (39.4 PSU) and a minimum during the rainy season (31.7 PSU).

\subsection{Thermoelectric power plant}

The combined cycle thermoelectric power plant "Jose Aceves Pozos" is located near the center of the Intermediate Area (Figure 1). It has three bunker fuel oil generating units with a 616 GWh design generation, 4,131 MW capacity and 76.3\% operational efficiency. A chimney releases the combustion gases from each unit. The thermoelectric power plant uses as cooling water the Urias Coastal Lagoon water, which is directly released to surface waters at a flow rate of $7.8 \mathrm{~m}^{3} \mathrm{~s}^{-1}$ and a $2-6{ }^{\circ} \mathrm{C}$ of overheating temperature (Alvarez León 1980).

\subsection{Model and forcings}

To simulate the Urias coastal lagoon hydrodynamics we used the Stony Brook Parallel Ocean Model (Jordi and Wang 2012), a parallelized version of the Princeton Ocean Model (POM, Blumberg and Mellor 1987). POM is a state-of-the-art numerical solver for the primitive equations of the ocean that has been extensively used to simulate conditions in estuaries ( $\mathrm{Xu}$ et al. 2013), semi-enclosed seas (Bernardello et al. 2012) and the open and global ocean (Barron et al. 2006). POM is a threedimensional sigma coordinate (terrain-following) model and includes the level-2.5 Mellor-Yamada turbulence closure scheme (Mellor 2004). To simulate the complex dynamics of this water body, we implemented an orthogonal grid with horizontal resolution of $50 \mathrm{~m}$ resulting in a matrix of $254 \mathrm{x} 106$ elements, whereas 8 unevenly distributed sigma levels were used to represent the vertical dimension. The model was forced with tidal sea-surface oscillation at its southern open boundary (the harbor entrance) as follows (Godin 1972):

$$
\zeta=\zeta_{\circ} \cos (\omega t-\varphi)
$$

where $\zeta, \omega$ and $\varphi$ are the amplitude, angular frequency and phase for the harmonic tide, respectively. Cardoso-Mohedano et al. (2014) report that harmonics observed on real tide data from the Urias coastal lagoon are S2, M2, N2, K1, O1, with amplitudes of 0.369, 0.110, 0.117 and 0.088, and phases of 16.03, 97.24, 170.2, 81.02 and 111.5, respectively. 
At the southern open boundary, water temperature was prescribed using remote sensing monthly climate data for sea surface temperature from sensor MODIS-Aqua. At the surface boundary, the model was forced using archived forecast analysis data provided by the European Centre for Medium Range Weather Forecast (ECMWF) with a spatial resolution of $0.25^{\circ}$ and a time-step of 6 hours. The data set includes $2 \mathrm{~m}$ air and dew temperatures, total cloud cover, $10 \mathrm{~m}$ wind speed components and precipitation. These data were used as inputs to a set of bulk-formulas used to calculate heat and freshwater fluxes (Estournel et al. 2009). In order to simulate the characteristics of the cooling water flow from the thermoelectric power plant, we imposed the water cooling release as a continuous flow $\left(7.78 \mathrm{~m}^{3} \mathrm{~s}^{-1}\right)$ on the surface open boundary at the power plant location. In order to determine the potentially highest thermal pollution impact, we assumed that the plant continuously operated with the maximum overheating temperature $\left(6^{\circ} \mathrm{C}\right)$. In order to avoid model drift during the simulation, we performed a three-year spin-up to achieve a steady state solution and results from the fourth simulated year are presented here.

\subsection{Temperature measurement and comparison}

In order to compare model results with field data, we placed during 2013 two HOBO Water Temp Pro v2, with $\pm 0.02^{\circ} \mathrm{C}$ resolution at $25^{\circ} \mathrm{C}$ and $0.2^{\circ} \mathrm{C}$ accuracy over $0^{\circ}$ to $50^{\circ} \mathrm{C}$ ), one placed at a station nearby the thermoelectric power plant (named Thermal Impact Station) and another one closer to the harbor entrance (Reference Station). Probes were placed at a 3 meters depth and the temperature was measured continuously with a time resolution of 30 minutes.

In order to evaluate the cooling water overheat, we defined $\Delta T_{\text {data }}$ as the temperature in the Thermal Impacted Station minus the synchronous temperature in the Reference Station as:

$$
\Delta T_{\text {data }}=T_{\text {Thermal Impact Station }}-T_{\text {Reference Station }}
$$

We also defined $\Delta T_{\text {model }}$ as the simulated temperature with power plant release (thermal model) minus the simulated temperature without release (reference model) at the same time step, as:

$$
\Delta T_{\text {model }}=T_{\text {thermal model }}-T_{\text {reference model }}
$$

$T_{\text {thermal model }}$ and $T_{\text {reference model }}$ were calculated in the Thermal Station grid location.

\section{Results}

The reported lagoon water temperature ranges (Villalba 1989) show a close relationship with atmospheric temperature, with a minimum range of $22-23{ }^{\circ} \mathrm{C}$ during the coolest months (November to February) and a maximum range of $30-32{ }^{\circ} \mathrm{C}$ during the warmest months (July to September). Indeed, this is consistent with our measurements, as the minimum temperature in the Reference Station ranged from $21.5-22.5^{\circ} \mathrm{C}$ and the maximum range was $31.9-33.9^{\circ} \mathrm{C}$. The temperature in the Thermal Station had the same pattern, with a temperature minimum range of 22.8-23.8 and a maximum range of 32.8$34.8^{\circ} \mathrm{C}$. Furthermore, the measured average temperature (Table 1) was significantly higher in the Thermal Station than the Reference station (two-sided t-test, $\mathrm{p}<0.01$ ). These results indicated that the thermoelectric power plant overheats the local temperature by $1.23 \pm 0.02^{\circ} \mathrm{C}$. This was consistent with 
the model results, as the simulated temperature in the Thermal Station was significantly higher than in the Reference station leading to a simulated overheating of $1.4 \pm 0.4{ }^{\circ} \mathrm{C}$ (two-sample t-test, $\mathrm{p}<0.01$ ).

Figure 2. Measured (red) and simulated (blue) temperature evolution in the Reference Station, Urias coastal lagoon.

During the full measurement period, the simulated maximum temperatures were overestimated by $\sim 2{ }^{\circ} \mathrm{C}$ (Table 1). As this mainly occurred in the upper lagoon, we suggest that this might be due to i) the discrepancy between the natural interannual variability of the real atmospheric forcing and the mean sea surface temperature (climate data) used to force the model, and ii) to the fact that the model does not take into account the shadow effect produced by abundant mangrove forests in the upper lagoon, which might reduce the amount of radiant energy reaching the water mass. Anyhow, the simulated and measured temperatures were not significantly different in the Reference Station (twosample t-test, $\mathrm{p}=0.45$ ) and Thermal Station (two-sample t-test, $\mathrm{p}=0.88$ ).

The model reproduces well the tidally forced semi-diurnal temperature pattern (Figure 2), thus showing that, as expected, the lagoon temperature is governed not only by atmospheric forcing but also by the tidal currents. The simulation results indicated that the thermal plume was found within $1 \mathrm{~km}$ of the thermoelectric power plant (Figure 3) mostly following the shoreline, with little transversal transport.

Table 1. Measured and simulated temperatures in the Reference and Thermal stations.

Figure 3. Temperature model results and tidal current velocity during lagoon water inflow (left) and outflow (right) conditions.

The simulated monthly average temperature in the Thermoelectric Impact Station indicated that maximum temperatures occur in the warmest months: July $\left(36.17{ }^{\circ} \mathrm{C}\right)$, August $\left(36.92{ }^{\circ} \mathrm{C}\right)$ and September $\left(35.88{ }^{\circ} \mathrm{C}\right)$. The minimum temperatures occur in the coolest months: December $\left(24.21{ }^{\circ} \mathrm{C}\right)$, January $\left(22.95^{\circ} \mathrm{C}\right)$ and February $\left(23.38^{\circ} \mathrm{C}\right)$.

\section{Discussion}

Temperature is a fundamental parameter in marine ecosystems, as it allows life development and affects reproduction, growth and overall metabolism. Therefore, thermal pollution may cause perturbations to marine biota, especially in the tropical and subtropical zone, where the local temperature is near the upper tolerance limits of some marine organism (Langford 2009; Poornima et al. 2005). Verones and co-workers (2010) report that thermal pollution may contribute between 3\% and $>90 \%$ to ecosystem quality damage. Furthermore thermoelectric and nuclear power plants discharge other pollutants as such as chlorine (Fernández Torres et al. 2012; Poornima et al. 2005), heavy metals (Abdul-Wahab and Jupp 2009; Baba et al. 2003) and flue-gas desulphurization effluents (Mohsen 2004; Van Den Hende et al. 2011). These impacts may be more serious in eutrophic semienclosed coastal water bodies under significant environmental pressure (Jiang et al. 2013), as is the case of the Urias coastal lagoon. Therefore, models should be used to evaluate thermal impacts and as a management tool of other activities in coastal lagoons (Bedri et al. 2013).

In order to evaluate the Urias coastal lagoon thermal pollution, we measured the temperature close to 
the thermoelectric power plant cooling water release (Thermal Station) and near the harbor entrance (Reference Station). In addition, we used a high-resolution 3D model to simulate the impact of the plant cooling water release. Our results showed that in the Thermoelectric Impact Station the maximum temperature measured occurred in the warmest months $\left(32.8-34.8{ }^{\circ} \mathrm{C}\right)$ and these were significantly higher than in the Reference Station (average $\Delta T_{\text {data }}=1.23 \pm 0.02{ }^{\circ} \mathrm{C}$ ). The observed overheating was consistent with the model results $\left(1.4 \pm 0.4^{\circ} \mathrm{C}\right)$. Furthermore, the model reproduced well the semidiurnal tide behavior, which causes a natural thermal oscillation (Figure 2).

The simulated lagoon temperatures showed a $0.15-0.3{ }^{\circ} \mathrm{C} \mathrm{km}{ }^{-1}$ longitudinal thermal gradient, increasing from the harbor entrance to the upper lagoon, as described by Villalba (1986). The lagoon temperature depends on many factors, e.g. cloud cover, solar radiation, wind, heat exchange with the atmosphere and tidal currents. These factors cause high thermal variability, as shown in Figure 4, thus introducing a high degree of complexity in the accurate assessment of the thermal impact. Therefore, in order to assess the plant thermal plume, we compared the lagoon temperature with and without thermal releases, but maintaining the same model forcing.

Figure 4. Measured thermal impact $\left(\Delta T_{\text {data }}\right)\left[{ }^{\circ} \mathrm{C}\right]$ (blue), annual average (black) and standard deviation (red).

The model results $\left(\Delta T_{\text {model }}\right)$ indicated that the average overheat isoline $\left(1.4{ }^{\circ} \mathrm{C}\right)$ was horizontally restricted to $\sim 100 \mathrm{~m}$ from the thermal release point and that the thermal plume was stretched along the shoreline (Figure 5), thus showing no effective estuarine transversal transport. Furthermore, the thermal impact was vertically restricted to the surface layer (above $0.6 \mathrm{~m}$ ) (Figure 6). Our results were consistent with Teixeira and-co-workers (2012), who report that for a nuclear power plant in a Southeastern Brazil coastal area, the thermal plume is restricted to the surface layer, with a $\sim 2{ }^{\circ} \mathrm{C}$ temperature difference between surface and bottom waters; thus temperature increment would not affect the benthic cover. Also Lardicci and co-workers (1999) observe that the heated effluent from a power plant on the Gulf of Follonica, Italy, does not affect the structure and spatial distribution of the benthic communities. Poornima and co-workers (2005) report that the impact of a thermoelectric power plant on the east coast of India is quite confined and does not affect phytoplankton communities. Finally, Martinez-Arroyo and Abundes (2000) observe that the water overheat (5.3-9.2 ${ }^{\circ} \mathrm{C}$ ) from a coastal thermoelectric power plant on the Gulf of Mexico does not affect the algal community structure but the thermal pollution affects the algal photosynthesis behavior.

Figure 5. Annual mean of the thermal impact $\left(\Delta T_{\text {model }}\right)$. The blank line corresponds to the annual average overheating $\left(1.4^{\circ} \mathrm{C}\right)$.

In order to estimate the potential thermal pollution impact on Urias coastal lagoon biota, we summarized upper temperature limits for growth of several species living in the lagoon (Table 2). From the reported limits, it can be concluded that the cooling water releases from the thermoelectric power plant may only directly affect invertebrates, since the maximum temperature $\left(36.9{ }^{\circ} \mathrm{C}\right)$ only exceeded upper temperature limits for growth for invertebrates $\left(35^{\circ} \mathrm{C}\right)$ during the warmest months.

Although the thermoelectric power plant overheat did not reach upper temperature limits for growth for other species, it could indirectly affect local biota. Ferrando and Mendez (2011) report that benthic 
fauna close to the thermoelectric power plant release point is perturbed in the warm season (August). However, our results indicate that the thermal impact is restricted to the surface layer (Figure 6), thus the plant cooling water release could not affect directly the benthic ecosystems. On the other hand, the high concentration of organic matter, present in eutrophic environments such as the Urias coastal lagoon (Ochoa-Izaguirre 2013), deplete oxygen concentration in the water column, and the high thermal stratification could reduce the atmospheric oxygen diffusivity toward the water column. Therefore, our results suggest that the observed impact in the lagoon may be caused by oxygen deficit, caused by eutrophication and strong thermal stratification, rather than by the thermal plume itself. Indeed, the effects of thermal pollution could be aggravated by i) eutrophication, causing oxygen depletion, due to urban and shrimp farm discharges (Jiang 2013) occurring also at the Urias coastal lagoon (Paez-Osuna et al. 1997), and ii) by enhanced stratification caused by water overheating. These effects have not been reported in the Urias coastal lagoon and merit further research.

A different picture emerges when global warming by Climate Change is considered. In the $5^{\text {th }}$ Assessment Report, the IPCC (2013) reports that, depending on the Representative Concentration Pathway (RCP) scenario and based on 12 Atmosphere-Ocean General Circulation Models, the median global ocean sea surface temperature change by 2100 will range from $0.6{ }^{\circ} \mathrm{C}\left(0.4^{\circ} \mathrm{C}\right.$ lower $90 \%$ range band) in the lowest radiative forcing scenario (RCP2.6) and $1.5^{\circ} \mathrm{C}\left(2.0^{\circ} \mathrm{C}\right.$ upper $90 \%$ range band) in the highest radiative forcing scenario (RCP8.5). When considering the scenario medians, and assuming no other effects than the impact of the global ocean temperature rise, the projected maximum temperatures in the Urias coastal lagoon would range from $37.5{ }^{\circ} \mathrm{C}$ to $38.4{ }^{\circ} \mathrm{C}$, and considering the $90 \%$ bands, these would range from $37.3^{\circ} \mathrm{C}$ to $38.9^{\circ} \mathrm{C}$. These ranges include the upper temperature limit for growth in the case of fish and other aquatic vertebrates of $38{ }^{\circ} \mathrm{C}$ (Table 2; Brock 1978). This suggests that, under the currently considered Climate Change scenarios, by 2100 the maximum temperature in the Urias coastal lagoon might directly affect fish growth, thus affecting the ecosystem and socio-economic activities such as fishing and aquaculture. Further work is needed to produce specific projections for the Urias coastal lagoon and to quantify the thermal tolerance of relevant fish species in the region.

Table 2. Temperature indicator organisms in Urias coastal lagoon.

Figure 6. Simulated $\Delta T_{\text {model }}$ (red area), $T_{\text {thermal model }}$ (red line) and $T_{\text {reference model }}$ (blue line) profile in the Thermoelectric Impact Station.

\section{Conclusions}

The Urias coastal lagoon showed large temperature variations, ranging from $21.5-22.8{ }^{\circ} \mathrm{C}$ in winter to 31.9-33.9 ${ }^{\circ} \mathrm{C}$ in summer in the Reference Station. Near the thermoelectric power plant (Thermoelectric Impact Station), temperatures ranged from $22.8-23.8{ }^{\circ} \mathrm{C}$ in winter to $32.8-34.8{ }^{\circ} \mathrm{C}$ in summer. The measured and modelled water overheat near the plant was $\sim 1.23{ }^{\circ} \mathrm{C}$ and $\sim 1.4{ }^{\circ} \mathrm{C}$, indicating a good performance of the model. Numerical simulation results showed that the temperature in the lagoon is strongly influenced by tides. Model results showed that the plant thermal impact was vertically restricted to the surface layer $(>0.6 \mathrm{~m})$ and horizontally restricted to $\sim 100 \mathrm{~m}$ from the release point. The thermal plume was distributed only along the shoreline and, therefore, there was no effective transversal transport. 
The maximum modelled overheating could reach upper temperature limits for growth only for some invertebrates during the warmest months. However, the plant thermal impact could be aggravated by the conjunction of cooling water release and other lagoon environmental stressors, such as oxygen depletion caused by eutrophication. Furthermore, in the current Climate Change IPCC scenarios, by 2100 the maximum temperature in the Urias coastal lagoon might directly affect fish growth, thus affecting the ecosystem and socio-economic activities such as fishing and aquaculture. The results of this study may be useful for the study of other tropical coastal lagoons that receive heat discharges.

\section{Acknowledgements}

The authors thank to Dirección General de Cómputo y de Tecnologías de Información y Comunicación of the Universidad Nacional Autónoma de México (UNAM) for the use of Miztli Cluster, where simulations were performed. Some preliminary simulations were carried on the supercomputer FinisTerrae hosted at the Centre of Supercomputing of Galicia (CESGA) and financed by the regional government of Galicia and the Spanish National Research Council (CSIC). Authors acknowledge partial financial support from the projects: Observatorio del Cambio Global en la zona costera de Mazatlán, Programa de Apoyos a Proyectos de Investigación e Innovación Tecnológica (PAPIIT, UNAM, IB201612); Renovación de equipo científico para el fortalecimiento de la investigación regional en Geoquímica Ambiental y Cambio Global (CONACYT INFR-2013-01 204818), Red Contaminación acuática niveles y efectos (PROMEP/103.5/12/4812). JGCM thanks for the financial support from Consejo Nacional de Ciencia y Tecnología (CONACyT) through a Doctoral (102137/43055) and a postdoctoral fellowship. We also thank technical support provided by Germán Ramírez Reséndiz (bathymetry and data management), Maria Clara Ramírez Jaúregui (bibliography), Onésimo López Ramos (dataloggers) and Paola Rodríguez Reynaga (language usage and editing service).

\section{References}

Abdul-Wahab, S. A., and Jupp, B. P. (2009). Levels of heavy metals in subtidal sediments in the vicinity of thermal power/desalination plants: a case study. Desalination, 244(1-3), 261-282. doi:10.1016/j.desal.2008.06.007

Alvarez-Leon, R. (1980). Hidrologia y zooplancton de tres esteros adyacentes a Mazatlán, Sinaloa, México. Anales Del Centro de Ciencias Del Mar Y Limnología - UNAM, 7(1), 177-194. Retrieved from http://biblioweb.tic.unam.mx/cienciasdelmar/centro/1980-1/articulo91.html

Alvarez-Leon, R. 1977. Estudio hidrológico de los esteros del Astillero, Urías y La Sirena adyacentes a Mazatlán, Sinaloa, México. Tesis profesional Universidad Nacional Autónoma de México, UACPyP, CCH. pp. 13

Baba, A., Kaya, A., and Birsoy, Y. K. (2003). The effect of Yatagan thermal power plant (Mugla, Turkey) on the quality of surface and ground waters. Water, Air, and Soil Pollution, 149(1-4), 93-111. doi:10.1023/A:1025660629875

Barron, C. N., Kara, A. B., Martin, P. J., Rhodes, R. C., and Smedstad, L. F. (2006). Formulation, implementation and examination of vertical coordinate choices in the Global Navy Coastal Ocean Model (NCOM). Ocean Modelling, 11(3-4), 347-375. doi:10.1016/j.ocemod.2005.01.004

Bedri, Z., Bruen, M., Dowley, A., and Masterson, B. (2013). Environmental consequences of a power plant shut-down: a three-dimensional water quality model of Dublin Bay. Marine Pollution Bulletin, 71(1-2), 117-28.

doi:10.1016/j.marpolbul.2013.03.025 
Bernardello, R., Cardoso, J. G., Bahamon, N., Donis, D., Marinov, I., and Cruzado, a. (2012). Factors controlling interannual variability of vertical organic matter export and phytoplankton bloom dynamics - a numerical case-study for the NW Mediterranean Sea. Biogeosciences, 9(11), 4233-4245. doi:10.5194/bg-9-4233-2012

Blumberg, A. F., and Mellor, G. L. (1987). A description of a three-dimensional coastal ocean circulation model. ThreeDimensional Coastal Ocean Models, 4, 1-16.

BP-AMOCO. (2002). BP Statistical Review of World Energy. BP Amoco. Retrieved from http://www.bp.com/

Brock, D. T. (1978). Thermophilic microorganisms and life at high temperatures. Cap 3. The organisms: General overview: 39-71. Springer-Verlag 465 pp.

Cardoso-Mohedano, J. G., Bernardello R., Sanchez-Cabeza J.A., Molino-Minero-Re, E., Cruzado. A. (2014). Accumulation of conservative substances in tropical coastal lagoons: nitrogen releases from shrimp aquaculture. Marine Pollution Bulletin. Submitted.

CONAGUA. (2011). Estadísticas del agua en México (p. 181). Mexico City. Retrieved from http://www.conagua.gob.mx/

Crema, R., and Pagliai, A. M. B. (1980). The structure of benthic communities in an area of thermal discharge from a coastal power station. Marine Pollution Bulletin, 11(8), 221-224. doi:10.1016/0025-326X(80)90410-5

Estournel, C., Auclair, F., Lux, M., Nguyen, C., and Marsaleix, P. (2009). “Scale oriented” embedded modeling of the North-Western Mediterranean in the frame of MFSTEP. Ocean Science, 5(2), 73-90.

Fajer-Avila, E. J., García-Vásquez, A., Plascencia-González, H., Ríos-Sicairos, J., García-De La Parra, L. M., and Betancourt-Lozano, M. (2006). Copepods and larvae of nematodes parasitizing (correction of parasiting) the white mullet Mugil curema (Valenciennes, 1836): indicators of anthropogenic impacts in tropical coastal lagoons? Environmental Monitoring and Assessment, 122(1-3), 221-37. doi:10.1007/s10661-005-9177-2

Fernández Torres, M. J., and Ruiz Beviá, F. (2012). Chlorine use reduction in nuclear or conventional power plants: a combined cooling-and-stripping tower for coastal power plants. Journal of Cleaner Production, 26, 1-8. doi:10.1016/j.jclepro.2011.12.016

Ferrando, A., and Mendez, N. (2011). Effects of organic pollution in the distribution of annelid communities in the Estero de Urías coastal lagoon, Mexico. Scientia Marina, 75(2), 351-358. doi:10.3989/scimar.2011.75n2351

García-Guerrero, M. and Hendrickx, M. (2003). Distribution of isopods (Peracarida, Isopoda) associated with prop roots of Rhizophora mangle in a tropical coastal lagoon, southeastern Gulf of California, Mexico. Crustaceana, 76(10), 11531169. doi:10.1163/156854003773123393

GESAMP. (1984). Thermal discharges in the marine environment. IMO/FAO/UNESCO/WMO/WHO/IAEA/UNEP. Joint group of experts on the scientific aspects of marine pollution. Reports and Studies No. 24

Godin, G. (1972). The analysis of tidal records (pp. 202-213). Liverpool: Liverpol University Press.

IEA. (1998). Key World Energy Statistics. International Energy Agency. Retrieved from http://www.iea.org/publications/

INEGI. (2013). México en cifras. Retrieved from http://www3.inegi.org.mx/sistemas/mexicocifras/

Jiang, Z., Liao, Y., Liu, J., Shou, L., Chen, Q., Yan, X., ... Zeng, J. (2013). Effects of fish farming on phytoplankton community under the thermal stress caused by a power plant in a eutrophic, semi-enclosed bay: Induce toxic dinoflagellate (Prorocentrum minimum) blooms in cold seasons. Marine Pollution Bulletin, 76(1-2), 315-324. doi:10.1016/j.marpolbul.2013.07.006 
Jiang, Z., Zeng, J., Chen, Q., Huang, Y., Xu, X., Liao, Y., ... Liu, J. (2008). Tolerance of copepods to short-term thermal stress caused by coastal power stations. Journal of Thermal Biology, 33(7), 419-423. doi:10.1016/j.jtherbio.2008.06.008

Jordi, A., and Wang, D.-P. (2012). sbPOM: A parallel implementation of Princenton Ocean Model. Environmental Modelling \& Software, 38(0), 59-61. doi:10.1016/j.envsoft.2012.05.013

Kimmerer, W., and Weaver, M. J. (2013). Climate Vulnerability. Climate Vulnerability (pp. 271-292). Elsevier. doi:10.1016/B978-0-12-384703-4.00438-X

Langford, T. (1990). Ecological Effects of Thermal Discharges (p. 468). Springer.

Langford, T. E. L. (2009). Thermal Discharges and Pollution. Encyclopedia of Ocean Sciences(Second Edition), 10-17. doi:10.1016/B978-012374473-9.00051-5

Lankford, R.R. 1977. Coastal lagoon of México: their origin and classification. 182-215 pp. En: Wiley, M., (ed). Estuarine Processes. Academic Press Inc., New York, U.S.A.

Lardicci, C., Rossi, F., Maltagliati, F., and Lardicci C., R. F. M. F. (1999). Detection of thermal pollution: Variability of benthic communities at two different spatial scales in an area influenced by a coastal power station. Marine Pollution Bulletin, 38(4), 296-303. doi: 10.1016/S0025-326X(98)00149-0

Martinez-Arroyo, A., and Abundes, S. (2000). On the influence of hot-water discharges on phytoplankton communities from a coastal zone of the Gulf of Mexico. Water, Air, and Soil Pollution 119: 209-230.

Doi:10.1023/A:1005161309609

Mellor, G. (2004). A Three-Dimensional, Primitive Equation, Numerical Ocean Model. User Guide. Princeton University, Princeton, NJ 08544-0710.

Mohsen, M. S. (2004). Treatment and reuse of industrial effluents: case study of a thermal power plant. Desalination, 167(1-3), 75-86. doi:10.1016/j.desal.2004.06.115

Montaño-Ley, Y., Peraza-Vizcarra, R., and Páez-Osuna, F. (2008). Tidal Hydrodynamics and their Implications for the Dispersion of Effluents in Mazatlán Harbor: An Urbanized Shallow Coastal Lagoon. Water, Air, and Soil Pollution, 194(1-4), 343-357. doi:10.1007/s11270-008-9721-0

Nordell, B. (2003). Thermal pollution causes global warming. Global and Planetary Change, 38(3-4), 305-312. doi:10.1016/S0921-8181(03)00113-9

Ochoa-Izaguirre, M. J. (1999). Composición y distribución de macroalgas en el sistema lagunar de Urías (Mazatlán, Sinaloa, México): variación estacional de la biomasa en realción con la disponibilidad de nutrientes y algunos factores ambientales. Universidad Nacional Autónoma de México. Master thesis.

Ochoa-Izaguirre, M. J., and Soto-Jímenez, M. F. (2013). Evaluation of nitrogen sources in the Urías lagoon system, Gulf of California, based on stable isotopes in macroalgae. Ciencias Marinas, 39, 413-430.

Ochoa-Izaguirre, M. J., Carballo, J. L., and Páez-Osuna, F. (2002). Qualitative changes in macroalgal assemblages under two contrasting climatic conditions in a subtropical estuary. Botanica Marina, 45(2), 130-138.

Paez-Osuna, F., Guerrero-Galvan, S. R., Ruiz-Fernandez, A. C., Espinoza-Angulo, R., and Marina, L. D. Q. (1997). Fluxes and mass balances of nutrients in a semi-intensive shrimp farm in north-western Mexico. Marine Pollution Bulletin, 34(5), 290-297. doi:10.1016/S0025-326X(96)00133-6 
Piñón-Gimate, A., Serviere-Zaragoza, E., Ochoa-Izaguirre, M. J., and Páez-Osuna, F. (2008). Species composition and seasonal changes in macroalgal blooms in lagoons along the southeastern Gulf of California. Botanica Marina, 51(2), 112-123. doi:10.1515/BOT.2008.013

Poornima, E. H., Rajadurai, M., Rao, T. S., Anupkumar, B., Rajamohan, R., Narasimhan, S. V., ... Venugopalan, V. P. (2005). Impact of thermal discharge from a tropical coastal power plant on phytoplankton. Journal of Thermal Biology, 30(4), 307-316. doi:10.1016/j.jtherbio.2005.01.004

Salgado-Barragán, J., and Toledano-Granados, A. (2006). The False Mussel Mytilopsis adamsi Morrison, 1946 (Mollusca: Bivalvia: Dreissenidae) in the Pacific Waters of Mexico: A Case of Biological Invasion. Hydrobiologia, 563(1), 1-7. doi:10.1007/s10750-005-1077-5

Stocker, T.F., D. Qin, G.-K. Plattner, L.V. Alexander, S.K. Allen, N.L. Bindoff, F.-M. Bréon, J.A. Church, U. Cubasch, S. Emori, P. Forster, P. Friedlingstein, N. Gillett, J.M. Gregory, D.L. Hartmann, E. Jansen, B. Kirtman, R. Knutti, K. Krishna Kumar, P. Lemke, J. Marotzke, V. Masson-Delmotte, G.A. Meehl, I.I. Mokhov, S. Piao, V. Ramaswamy, D. Randall, M. Rhein, M. Rojas, C. Sabine, D. Shindell, L.D. Talley, D.G. Vaughan and S.-P. Xie, 2013: Technical Summary. In: Climate Change 2013: The Physical Science Basis. Contribution of Working Group I to the Fifth Assessment Report of the Intergovernmental Panel on Climate Change [Stocker, T.F., D. Qin, G.-K. Plattner, M. Tignor, S.K. Allen, J. Boschung, A. Nauels, Y. Xia, V. Bex and P.M. Midgley (eds.)]. Cambridge University Press, Cambridge, United Kingdom and New York, NY, USA.

Teixeira, T. P., Neves, L. M., and Araújo, F. G. (2009). Effects of a nuclear power plant thermal discharge on habitat complexity and fish community structure in Ilha Grande Bay, Brazil. Marine Environmental Research, 68(4), 188195. doi:10.1016/j.marenvres.2009.06.004

Teixeira, T. P., Neves, L. M., and Araújo, F. G. (2012). Thermal impact of a nuclear power plant in a coastal area in Southeastern Brazil: effects of heating and physical structure on benthic cover and fish communities. Hydrobiologia, 684(1), 161-175. doi:10.1007/s10750-011-0980-1

Tovar-Hernández, M. A. (2014). Aracia sinaloae sp. n., a new brooding, simultaneous hermaphroditic fan worm from southern Gulf of California (Polychaeta: Sabellidae). Zootaxa, 3784(4), 389-400. doi:10.11646/zootaxa.3784.4.3

Van Den Hende, S., Vervaeren, H., Desmet, S., and Boon, N. (2011). Bioflocculation of microalgae and bacteria combined with flue gas to improve sewage treatment. New Biotechnology, 29(1), 23-31. doi:10.1016/j.nbt.2011.04.009

Verones, F., Hanafiah, M. M., Pfister, S., Huijbregts, M. a J., Pelletier, G. J., and Koehler, A. (2010). Characterization factors for thermal pollution in freshwater aquatic environments. Environmental Science \& Technology, 44(24), 9364-9. doi:10.1021/es102260c

Villalba, L. A. (1989). Descripción general del estero de Urías, Mazatlán, Sinaloa. Ciencias Del Mar, 8, 32-37.

Wither, A., Bamber, R., Colclough, S., Dyer, K., Elliott, M., Holmes, P., ... Turnpenny, A. (2012). Setting new thermal standards for transitional and coastal (TraC) waters. Marine Pollution Bulletin, 64(8), 1564-1579. doi:10.1016/j.marpolbul.2012.05.019

Xu, B.-C., Dimova, N. T., Zhao, L., Jiang, X.-Y., and Yu, Z.-G. (2013). Determination of water ages and flushing rates using short-lived radium isotopes in large estuarine system, the Yangtze River Estuary, China. Estuarine, Coastal and Shelf Science, 121-122, 61-68. doi:10.1016/j.ecss.2013.02.005 